Article

\title{
Cultivable Alginate Lyase-Excreting Bacteria Associated with the Arctic Brown Alga Laminaria
}

\author{
Sheng Dong, Jie Yang, Xi-Ying Zhang, Mei Shi, Xiao-Yan Song, Xiu-Lan Chen * and \\ Yu-Zhong Zhang
}

State Key Lab of Microbial Technology, Marine Biotechnology Research Center, Shandong University, Jinan 250100, China; E-Mails: Ds518@126.com (S.D.); 645670894@qq.com (J.Y.); zhangxiying@sdu.edu.cn (X.-Y.Z.); clubstone@sdu.edu.cn (M.S.); xiaoyansong@sdu.edu.cn (X.-Y.S.); zhangyz@sdu.edu.cn (Y.-Z.Z.)

* Author to whom correspondence should be addressed; E-Mail: cx10423@sdu.edu.cn; Tel.: +86-531-88364326; Fax: +86-531-88564326.

Received: 15 August 2012; in revised form: 24 September 2012 / Accepted: 26 October 2012 / Published: 6 November 2012

\begin{abstract}
Although some alginate lyases have been isolated from marine bacteria, alginate lyases-excreting bacteria from the Arctic alga have not yet been investigated. Here, the diversity of the bacteria associated with the brown alga Laminaria from the Arctic Ocean was investigated for the first time. Sixty five strains belonging to nine genera were recovered from six Laminaria samples, in which Psychrobacter (33/65), Psychromonas (10/65) and Polaribacter (8/65) were the predominant groups. Moreover, 21 alginate lyase-excreting strains were further screened from these Laminaria-associated bacteria. These alginate lyase-excreting strains belong to five genera. Psychromonas (8/21), Psedoalteromonas (6/21) and Polaribacter (4/21) are the predominant genera, and Psychrobacter, Winogradskyella, Psychromonas and Polaribacter were first found to produce alginate lyases. The optimal temperatures for the growth and algiante lyase production of many strains were as low as $10-20^{\circ} \mathrm{C}$, indicating that they are psychrophilic bacteria. The alginate lyases produced by 11 strains showed the highest activity at $20-30{ }^{\circ} \mathrm{C}$, indicating that these enzymes are cold-adapted enzymes. Some strians showed high levels of extracellular alginate lyase activity around $200 \mathrm{U} / \mathrm{mL}$. These results suggest that these algiante lyase-excreting bacteria from the Arctic alga are good materials for studying bacterial cold-adapted alginate lyases.
\end{abstract}

Keywords: alginate lyase-excreting bacteria; psychrophilic; Arctic; Laminaria; diversity 


\section{Introduction}

Alginate is a liner unbranched copolymer of $\alpha$-L-guluronate (G) and its C5 epimer, $\beta$-D-mannuronate $(\mathrm{M})$, arranged in block structures such as homopolymeric $\mathrm{G}$ block, $\mathrm{M}$ block, alternating $\mathrm{MG}(\mathrm{GM})$ block, and heteropolymeric $\mathrm{MG}(\mathrm{GM})$ block [1]. Its unique physical properties to form gels enable it to be used widely as stabilizer, viscosifier, and gelling agent [2,3]. Alginate lyases degrade alginate by a $\beta$-elimination mechanism that generate a product containing 4-deoxy-L-erythro-hex-4-enopyranosyluronic acid as the non-reducing terminal moiety [4]. The non-reducing end groups of the products generate an increasing absorbance at $235 \mathrm{~nm}$, which can be used to monitor real-time alginate lyase activity $[5,6]$. Alginate lyases are classified into three groups by their substrate specificity: the first type is specific toward G block (EC4.2.2.11), the second type is specific toward M block (EC4.2.2.3), and the third type is bifunctional for G and M block. Furthermore, alginate lyases are also grouped into three classes by their molecular masses: $20-35 \mathrm{kDa}$ class, $\sim 40 \mathrm{kDa}$ class, and $\sim 60 \mathrm{kDa}$ class [7]. Based on their primary structures, alginate lyases are classified into seven families (PL5, 6, 7, 14, 15, 17 and 18) [8].

Alginate lyases are reported from various resources, including marine algae, marine mollusks, fungi, bacteria, bacteriophages, and viruses [9]. Because alginate is of great abundance as part of the cell wall and intracellular material in brown alga, some alginate lyase-excreting strains are separated from brown alga, such as Pseudoalteromonas elyakoii IAM 14594 from the spot-wounded fronds of Laminaria japonica [10] and Pseudoalteromonas sp. SM0524 from rotten kelp [11]. However, study on the diversity of brown alga-associated bacteria has been rather less extensive. Lee et al. (2006) isolated 66 strains from Korean brown alga Undaria pinnatifida [12], which represents the best investigation on the diversity of alga-associated bacteria to our knowledge. Moreover, the diversity of the alginate lyase-excreting bacteria associated with brown algae has not been reported.

The Arctic Ocean is the most extreme ocean regarding the seasonality of light and its year-round existing ice cover. A large number of unique life forms are highly adapted to the extreme environment of the Arctic Ocean in their ecology and physiology. Brown alga growing in the intertidal zone of the Arctic Ocean is a potential resource for the discovery of new bacteria producing novel alginate lyases, which, however, have never been investigated. In this paper, the diversity of cultivable bacteria associated with the brown alga Laminaria collected from the Arctic Ocean was investigated, and the alginate lyase-excreting bacteria were isolated from these samples and identified. Moreover, the alginate lyase production of these bacteria was detected, and the optimal temperatures for bacterial growth, alginate lyase production and the activity of alginate lyase from each strain were measured. The results are beneficial for exploring novel alginate lyase from the Arctic Ocean.

\section{Materials and Method}

\subsection{Materials}

Sodium alginate ( $250 \mathrm{cps})$ from brown algae was purchased from sigma (USA). The plasmid pMD-18-T (Takara) and Escherichia coli DH5 $\alpha$ were used for cloning and sequencing of 16S rRNA genes. The clones were grown on LB agar or liquid medium containing $100 \mu \mathrm{g} / \mathrm{mL}$ of ampicillin at $37^{\circ} \mathrm{C}$. Algal samples were collected from six locations in the intertidal zone of the Kings Bay in 
Ny-Ålesund, Svaldbard during the Chinese Arctic Yellow River Station Expedition in July, 2011. The numbers and locations of the six samples were shown in Table 1. The algal samples were stored in airtight sterile plastic tube at $4{ }^{\circ} \mathrm{C}$ until returning to the laboratory. The six algal samples were all identified as Laminaria sp.

Table 1. The locations of sampling stations.

\begin{tabular}{ccc}
\hline Station & \multicolumn{2}{c}{ Location } \\
\hline 0 & $78^{\circ} 55^{\prime} 3.0^{\prime \prime} \mathrm{N}$ & $11^{\circ} 58^{\prime} 14.0^{\prime \prime} \mathrm{E}$ \\
1 & $78^{\circ} 55^{\prime} 19.7^{\prime \prime} \mathrm{N}$ & $11^{\circ} 56^{\prime} 53.8^{\prime \prime} \mathrm{E}$ \\
2 & $78^{\circ} 55^{\prime} 17.0^{\prime \prime} \mathrm{N}$ & $11^{\circ} 57^{\prime} 0.2^{\prime \prime} \mathrm{E}$ \\
3 & $78^{\circ} 55^{\prime} 3.8^{\prime \prime} \mathrm{N}$ & $11^{\circ} 58^{\prime} 11.6^{\prime \prime} \mathrm{E}$ \\
$\mathrm{B}$ & $78^{\circ} 55^{\prime} 20.5^{\prime \prime} \mathrm{N}$ & $11^{\circ} 54^{\prime} 49.7^{\prime \prime} \mathrm{E}$ \\
$\mathrm{C}$ & $78^{\circ} 55^{\prime} 3.8^{\prime \prime} \mathrm{N}$ & $11^{\circ} 56^{\prime} 53.8^{\prime \prime} \mathrm{E}$ \\
\hline
\end{tabular}

\subsection{Enrichment Cultivation and Isolation of the Bacteria Associated with the Arctic Brown}

Alga Laminaria

Each Laminaria sample was cut into small pieces using sterile scissors. One gram of every sample was put in $100 \mathrm{~mL}$ of the enrichment medium containing marine broth 2216 (Difco) plus 1\% sodium alginate. After incubated at $15{ }^{\circ} \mathrm{C}, 200 \mathrm{rpm}$ for $8 \mathrm{~h}$, the culture broths were serially tenfold diluted to $10^{-6}$ dilution with sterile artificial sea water. Aliquots of $100 \mu \mathrm{L}$ diluted samples $\left(10^{-2}-10^{-6}\right.$ dilution) were spread on screening plates with a medium composed of $0.1 \%$ yeast extract, $0.5 \%$ tryptone, $1 \%$ sodium alginate, $1.5 \%$ agar powder and artificial seawater $(\mathrm{pH} 7.0)$. The plates were then incubated at $15{ }^{\circ} \mathrm{C}$ for a proper time to form detectable colonies. Morphologically different colonies were selected and further purified by repeatedly streaking on the same medium. The purified strains were stored in $10 \%$ glycerol at $-80{ }^{\circ} \mathrm{C}$.

\subsection{Screening of Alginate Lyase-Excreting Bacteria}

The purified isolates were, respectively, streaked on the plate with a medium containing $0.1 \%$ yeast extract, $0.5 \%$ tryptone, $0.4 \%$ sodium alginate, $1.5 \%$ agar powder and artificial seawater $(\mathrm{pH} 7.0)$. After being incubated at $15{ }^{\circ} \mathrm{C}$ for 4 days, the plates were stained by flooding with $10 \%$ (weight/volume) cetylpyridiniun chloride. If a strain excreted alginate lyase into the medium, a clear halo of depolymerization around the strain colony on a white background could be observed. Therefore, the isolates with a clear halo were selected as alginate lyase-excreting bacteria.

\subsection{Amplification, Cloning, and Sequencing of the $16 S$ rRNA Gene}

The genomic DNA of each isolate was extracted by using the BIOTEKE genomic DNA purification kit. The 16S rRNA genes were amplified from the genomic DNA by PCR with two primers (1492r: 5'-GGTTACCTTGTTACGACTT-3', 27f: 5'-AGAGTTTGATCCTGGCTCAG-3') [13]. The amplified DNA fragments of the $16 \mathrm{~S}$ rRNA genes were ligated into pMD-18-T cloning vectors (Takara) and sequenced by Biosune Inc. (Shanghai, China). Sequence alignment was performed using CLUSTAL X 
(v 1.83). Neighbor-joining trees were constructed using MEGA version 3.1 with neighbor-joining method and Kimura two parameter model [14].

\subsection{Assay for Alginate Lyase Activity}

Alginate lyase activity was quantitatively determined by measuring the amount of reducing sugars released from alginate by using the Somogyi-Nelson method [15]. Bacterial culture was centrifuged at $12,000 \times \mathrm{g}, 4^{\circ} \mathrm{C}$ for $12 \mathrm{~min}$. The supernatant was properly diluted with $20 \mathrm{mM}$ phosphate buffer (pH 7.0) if needed. Then, $20 \mu \mathrm{L}$ diluted culture supernatant was mixed with a $180 \mu \mathrm{L}$ solution composed of $20 \mathrm{mM}$ phosphate buffer $(\mathrm{pH} \mathrm{7.0)}$ ) and $0.5 \%$ sodium alginate. The mixture was incubated at an indicated temperature for $30 \mathrm{~min}$. After incubation, $200 \mu \mathrm{L}$ Nelson copper reagent was added, and then the mixture was bathed in boiling water for $15 \mathrm{~min}$, followed by a fast cool in ice bath. Then $100 \mu \mathrm{L}$ arsenomolybdate was added. Enzyme activity was determined by monitoring the absorbance increase at $680 \mathrm{~nm}$. A standard curve was prepared using mannose at concentrations ranging from 0.1 to $1 \mathrm{mM}$. One unit of enzyme activity was defined as the amount of protein that generates $1 \mathrm{nmol}$ reducing sugars per min. A blank control was set by mixing Nelson copper reagent and the substrate solution followed by an addition of culture supernatant to inactiviate the alginate lyase activity before incubation.

2.6. Analysis of the Optimal Temperatures for the Growth and Alginate Lyase Production of the Isolates and for the Activity of Alginate Lyase from Each Strain

The alginate lyase-excreting bacteria were cultivated in the liquid screening medium at series temperatures, from $10{ }^{\circ} \mathrm{C}$ to $35^{\circ} \mathrm{C}$ with an interval of $5{ }^{\circ} \mathrm{C}$, and $200 \mathrm{rpm}$ for 4 days. Timing sampling was done during the cultivation. The bacterial density in each sample was measured at a wavelength of $600 \mathrm{~nm}\left(\mathrm{OD}_{600}\right)$ to draw a growth curve. Each sample was centrifuged at $12,000 \times \mathrm{g}, 4{ }^{\circ} \mathrm{C}$ for $12 \mathrm{~min}$, and the supernatant was collected to measure the alginate lyase activity at its optimal temperature. The optimal temperature for alginate lyase activity was determined by measuring the enzyme activity from $10{ }^{\circ} \mathrm{C}$ to $60^{\circ} \mathrm{C}$ with an interval of $10^{\circ} \mathrm{C}$.

\section{Results}

\subsection{Diversity of Bacteria Associated with the Arctic Brown Alga Laminaria}

After cultivation of the bacteria enriched from the Arctic Laminaria on screening plates, a lot of colonies appeared on the plates with $10^{-2}-10^{-5}$ diluted samples. More than 70 isolates were purified and subjected to $16 \mathrm{~S}$ rRNA gene amplification. Isolates with the same (or only one base difference) $16 \mathrm{~S}$ rRNA gene sequence were considered as the same strain. According to an alignment of the 16S rRNA gene sequences, a total of 65 different strains were isolated from the Arctic Laminaria samples. A phylogenetic analysis based on the 16S rRNA gene sequences showed that the recovered Laminaria-associated bacteria belonged to nine genera, namely Cobetia, Psychrobacter, Winogradskyella, Psedoalteromonas, Psychromonas, Polaribacter, Shewanella, Flavobacterium and marinomonas (Figure 1). Psychrobacter (33/65) were the most predominant group. Psychromonas $(10 / 65)$ and Polaribacter (8/65) also showed some preponderance. 
Figure 1. A neighbor-joining phylogenetic tree of the bacteria recovered from the six Laminaria samples on the Arctic Ocean based on the 16S rRNA gene sequences. Branch 1 includes Psychromonas strains 0-7, 3-5, 3-6, 3-12, 3-14, C-2 and C-8. Branch 2 includes Psychrobacter strains 0-5, 0-10, 0-12, 0-13, 0-14, 0-15, 0-20, 1-1, 1-2, 1-3, 1-4, 1-5, 2-3, 2-4, 2-7, 2-10, 2-13, 2-14, 3-2, 3-3, 3-4, 3-7, 3-8, 3-9, 3-10, 3-11, 3-13, 3-15, 3-16 and 3-17, and Psychrobacter fozii NF23(T) (AJ430827). Branch 3 includes Polaribacter strains 0-11, 2-2, 2-5, 2-6, 2-8, 2-9, 2-16 and 2-17.

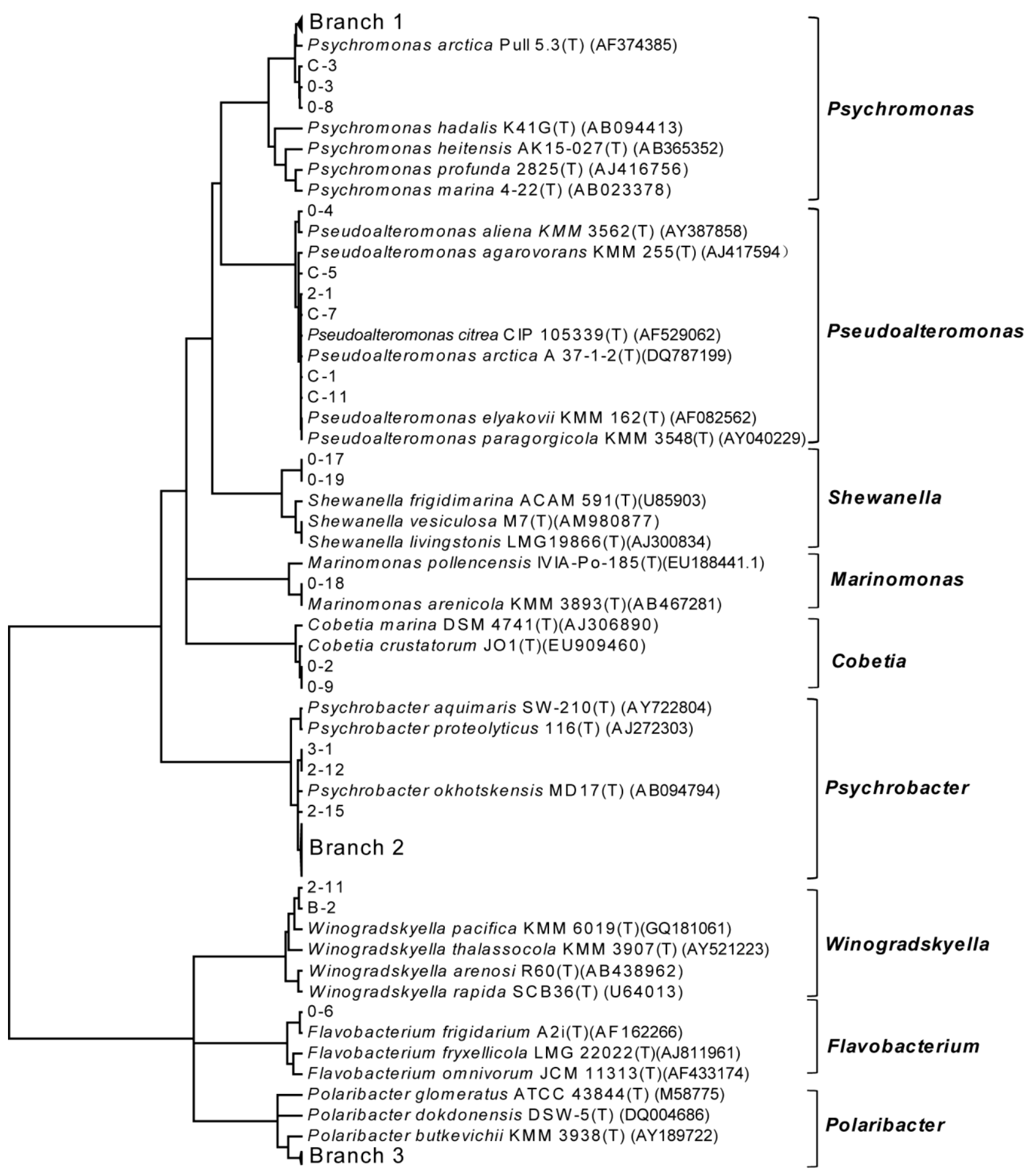




\subsection{Diversity of Alginate Lyase-Excreting Bacteria from the Arctic Brown Alga Laminaria}

Alginate lyase-excreting bacteria were further screened from the recovered Laminaria-associated isolates by screening plates. Twenty one strains showed clear haloes after $10 \%$ cetylpyridiniun chloride was flooded on the plates (Supplementary Materials, Figure S1), indicating that these strains could excrete alginate lyase. The 21 strains were taken as alginate lyase-excreting bacteria for further study. These strains belonged to five genera, namely Psychrobacter, Winogradskyella, Psedoalteromonas, Psychromonas and Polaribacter. Psychromonas (8/21), Psedoalteromonas (6/21) and Polaribacter (4/21) were the predominant genera (Figure 2). Therefore, it seemed that the predominant genera of the Laminaria-associated bacteria and the alginate lyase-excreting bacteria showed some difference.

Figure 2. Abundances of the phylotypic groups of cultivable alginate lyase-excreting bacteria recovered from the brown alga Laminaria from six sample stations on the Arctic Ocean.

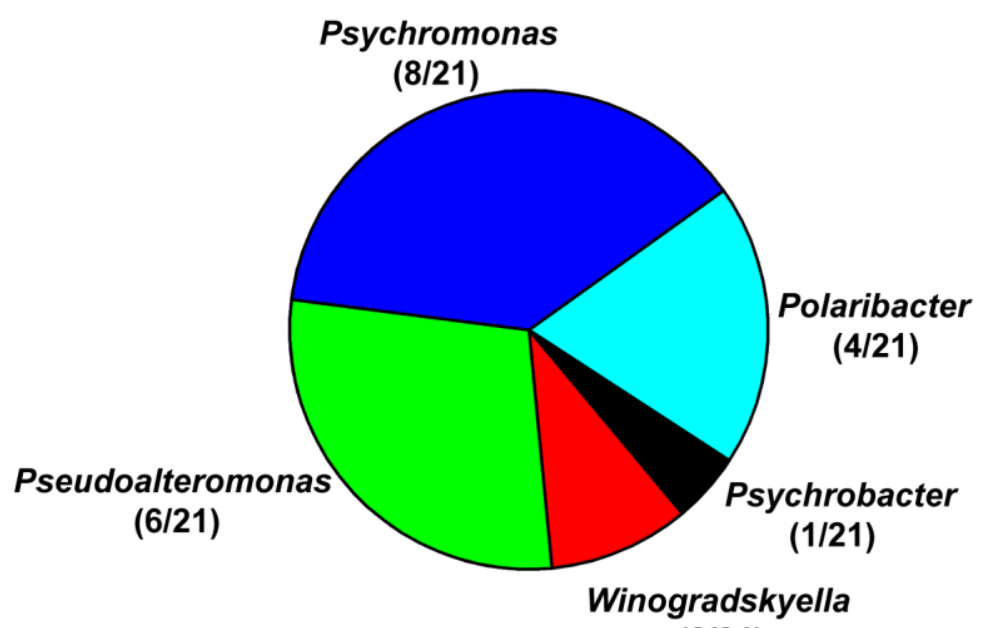

$(2 / 21)$

A distance-based neighbor-joining tree was constructed with the 16S rRNA gene sequences of the alginate lyase-excreting bacteria in this study and reference sequences from the GenBank database (Figure 3). There were three predominant branches, namely Psychromonas, Pseudoalteromonas and Polaribacter. Strains related to Psychromonas were the most frequently recovered (recovered from three Laminaria samples) and formed the largest group in terms of abundance (8 of 21 strains, Figure 3). These Psychromonas strains showed high similarity (more than 98.3\%) with Psychromonas arctica Pull $5.3^{\mathrm{T}}$ that was isolated from a seawater sample collected from Spitzbergen in the Arctic (Supplementary Materials, Table S1). Four strains, 2-2, 2-5, 2-9 and 2-17, showed high similarity (more than 98.5\%) with Polaribacter butkevichii KMM $3938^{\mathrm{T}}$ that was isolated from the seawater collected from the Sea of Japan, Russia. Strain 2-15 exhibited a distant relationship with any of the previously identified species. It may represent a potentially new species, which merits further study. 
Figure 3. A neighbor-joining phylogenetic tree of the alginate lyase-excreting bacteria recovered from the Arctic brown alga Laminaria based on the 16S rDNA sequences.

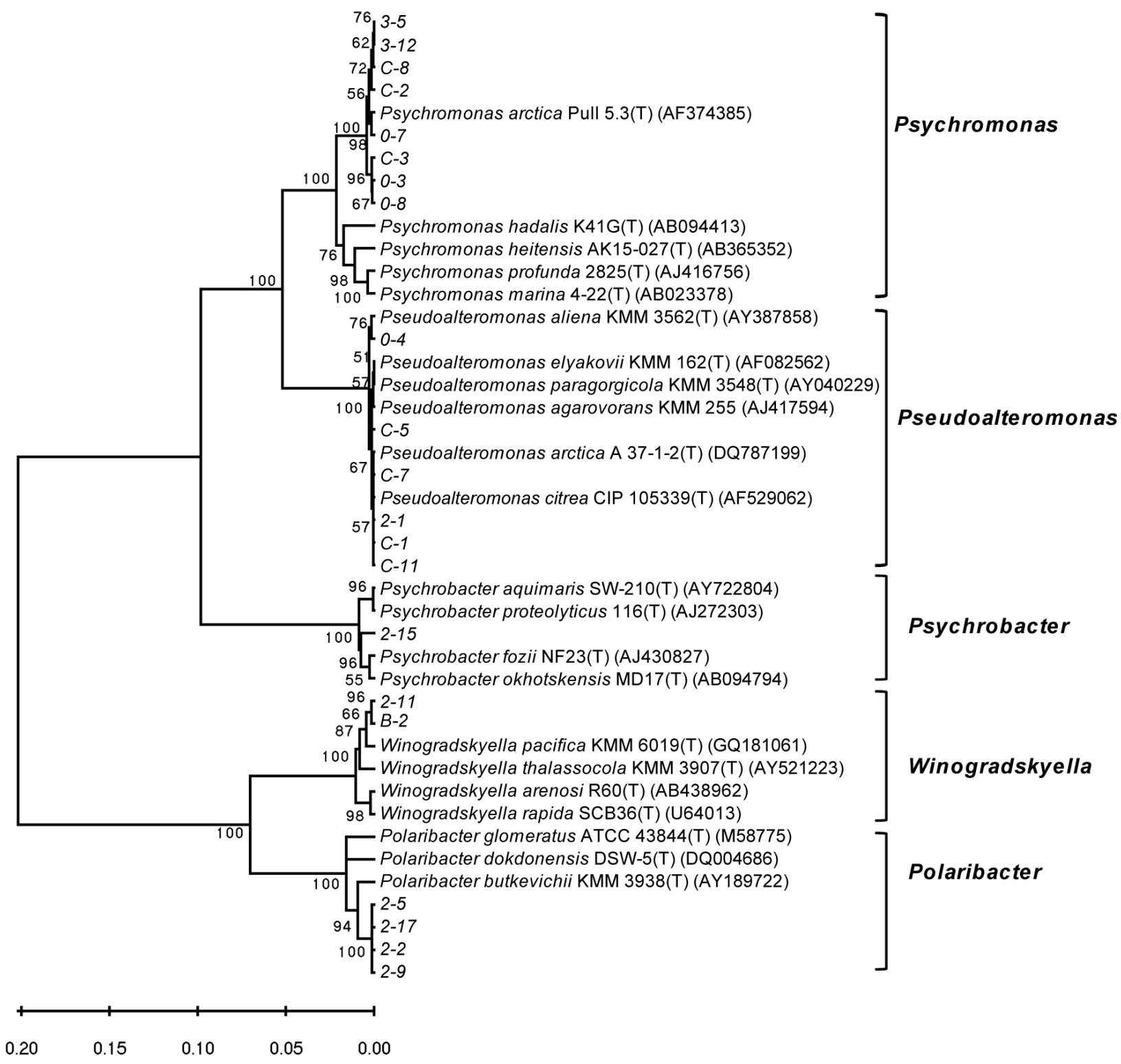

\subsection{Optimal Temperatures for Growth and Alginate Lyase Production of the Strains}

Among the 21 alginate lyase-excreting strains, 20 strains had the optimal temperatures for growth at $10-25{ }^{\circ} \mathrm{C}$, indicating that most alginate lyase-excreting strains are cold-adapted bacteria (Table 2). The optimal growth temperature was just $10{ }^{\circ} \mathrm{C}$ for strains $0-7$ and $2-1$, and $15{ }^{\circ} \mathrm{C}$ for strains $0-4,2-17$ and 3-12, showing that these five strains are psychrophiles. The other stains with an optimal growth temperature of $20^{\circ} \mathrm{C}, 25^{\circ} \mathrm{C}$ or $30^{\circ} \mathrm{C}$ are psychrotrophiles. Correspondingly, the optimal temperatures for the strains to produce alginate lyases were also low. Ten strains showed the same optimal temperature for growth and alginate lyase production. However, the optimal temperature for some strains to produce extracellular alginate lyases was lower than that for growth, such as strains $0-8,2-11$ and 3-12, while others showed higher optimal temperatures for alginate lyase production than for growth. In general, the strains showed low optimal temperatures for growth and extracellular enzyme production, reflecting their adaptation to the cold Arctic Ocean. 
Table 2. Optimal temperatures for growth and alginate lyase production of the strains and for the activity of the alginate lyase from each strain.

\begin{tabular}{|c|c|c|c|c|}
\hline \multirow[b]{2}{*}{ Genera } & \multirow[b]{2}{*}{ Strains } & \multicolumn{3}{|c|}{ Optimum Temperature $\left({ }^{\circ} \mathrm{C}\right)$} \\
\hline & & for Growth & $\begin{array}{l}\text { for Enzyme } \\
\text { Production }\end{array}$ & $\begin{array}{c}\text { for Enzyme } \\
\text { Activity }\end{array}$ \\
\hline \multirow{4}{*}{ Polaribacter } & $2-2$ & 20 & 25 & 30 \\
\hline & $2-9$ & 20 & 25 & 50 \\
\hline & $2-5$ & 25 & 25 & 50 \\
\hline & $2-17$ & 15 & 25 & 40 \\
\hline \multirow{6}{*}{ Pseudoalteromonas } & $0-4$ & 15 & 15 & 30 \\
\hline & $2-1$ & 10 & 25 & 40 \\
\hline & $\mathrm{C}-1$ & 30 & 25 & 20 \\
\hline & C-5 & 25 & 25 & 40 \\
\hline & $\mathrm{C}-7$ & 25 & 30 & 30 \\
\hline & $\mathrm{C}-11$ & 25 & 25 & 40 \\
\hline Psychrobacter & $2-15$ & 20 & 20 & 50 \\
\hline \multirow{8}{*}{ Psychromonas } & $0-3$ & 20 & 20 & 30 \\
\hline & $0-7$ & 10 & 20 & 45 \\
\hline & $0-8$ & 20 & 15 & 30 \\
\hline & $3-5$ & 20 & 20 & 30 \\
\hline & $3-12$ & 15 & 10 & 30 \\
\hline & $\mathrm{C}-2$ & 20 & 20 & 20 \\
\hline & $\mathrm{C}-3$ & 20 & 25 & 20 \\
\hline & $\mathrm{C}-8$ & 25 & 25 & 30 \\
\hline \multirow{2}{*}{ Winogradskyella } & $2-11$ & 20 & 15 & 40 \\
\hline & B-2 & 25 & 25 & 40 \\
\hline
\end{tabular}

\subsection{Optimal Temperatures for the Enzymatic Activity of the Alginate Lyases from the Strains}

The optimal temperatures for the extracellular alginate lyases produced by the 21 strains were ranged from $20{ }^{\circ} \mathrm{C}$ to $50{ }^{\circ} \mathrm{C}$ (Table 2). The alginate lyases produced by 11 strains showed the highest activity at $20-30{ }^{\circ} \mathrm{C}$, indicating the good cold-adaptation of these alginate lyases. The alginate lyases produced by the other 10 strains showed the highest activity at $40-50{ }^{\circ} \mathrm{C}$. The differences in the optimal temperatures for enzyme activity suggest that the alginate lyases excreted by these strains may be different kinds of alginate lyases. The results indicate that a majority of bacterial extracellular alginate lyases from the Arctic Ocean are cold-adapted enzymes.

\subsection{Levels of Extracellular Alginate Lyase Activity of the Strains}

The extracellular alginate lyase activity level of every strain was determined by measuring the alginate lyase activity in the culture at its optimal temperature (Figure 4). Among the 21 alginate lyase-excreting strains, strain 2-2 had the highest extracellular alginate lyase activity level, more than $200 \mathrm{U} / \mathrm{mL}$, while strain C-1 had the lowest extracellular alginate lyase activity level, lower than $60 \mathrm{U} / \mathrm{mL}$. Strains $0-4$ and C-11 also had a level of near $200 \mathrm{U} / \mathrm{mL}$. This indicated that these strains may be good candidates for isolation of novel alginate lyases. 
Figure 4. Extracellular alginate lyase activity levels of the strains. Each strain was cultured at its optimal temperature, and the alginate lyase activity at its optimal temperature for each strain was determined.

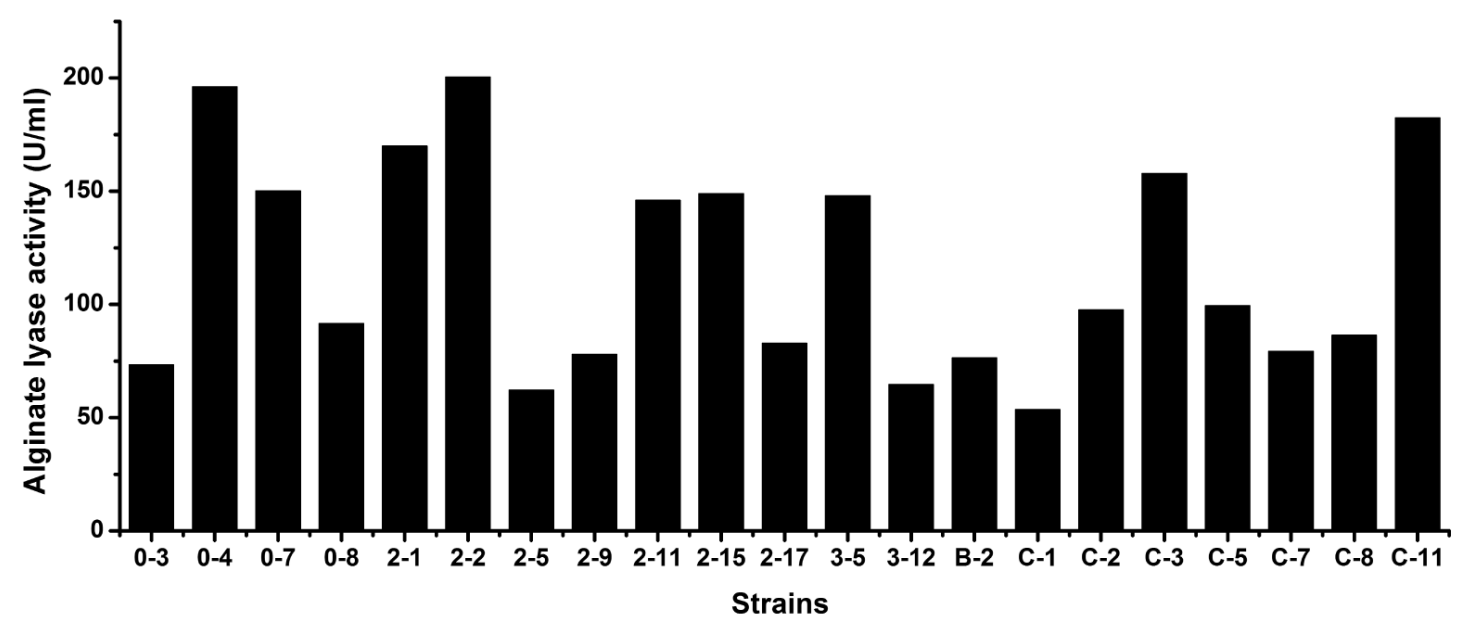

\section{Discussion}

Alginate lyases from bacterial sources have been used in analyzing alginate structure, protoplasting of seaweed, studying Fucus cell wall development, and producing polyM, or polyG blocks [16-20]. Recently alginate oligomers with the specific molecular weight have been shown to have specific bio-activities, such as stimulating the secretion of cytotoxic cytokines from human macrophage [21] or promoting the growth of bifidobacteria [22]. Alginate lyases can be used as tools for generating bio-active products. The use of alginate lyase for the treatment of cystic fibrosis suffers still remains one of the most important goals of studying alginate lyase [23]. Nowadays fossil fuel resources are running out and this has ignited efforts to produce bio-fuels and renewable commodity chemical compounds via microbial fermentation. An engineered microbial platform with a bifunctional alginate lyase aly-SJ02 was generated, which can simultaneously degrade, uptake and metabolize alginate [24]. Discovery of new alginate lyase will facilitate the application of alginate lyase in the production of biofuel and bioactive alginate hydrolysates.

Diversities of alga-associated bacteria and algiante lyase-excreting bacteria in the Arctic Ocean have not been reported. In this study, the diversity of alga-associated bacteria from 6 Laminaria samples was investigted, which showed that Psychrobacter, Psychromonas and Polaribacter were the most predominant groups of the 65 recovered Laminaria-associated bacteria. To dig the algiante lyase resource in the Arctic Ocean, algiante lyase-excreting bacteria were further screened from the 65 Laminaria-associated bacteria. Alginate lyase-excreting marine bacteria so far reported include Alginovibrio, Alteromonas, Beneckea, Halomonas, Photobacterium, Pseudoalteromonas and Vibro [9]. In this study, 21 algiante lyase-excreting strains were recovered from the Arctic brown alga Laminaria. Besides Pseudoalteromonas, it was first found that Psychrobacter, Winogradskyella, Psychromonas and Polaribacter excrete alginate lyases. Among these algiante lyase-excreting strains, the optimal temperatures for growth and algiante lyase production of many strains were as low as $10-20{ }^{\circ} \mathrm{C}$, showing that they are psychrophilic bacteria. And the alginate lyases excreted by 11 strains showed the highest activity at $20-30{ }^{\circ} \mathrm{C}$, indicating that these alginate lyases are cold-adapted enzymes. 
Moreover, some strains showed high extracellular alginate lyase activity levels around $200 \mathrm{U} / \mathrm{mL}$. These results suggest that the algiante lyase-excreting bacteria we recovered from the Arctic alga Laminaria may be good materials for studying bacterial cold-adapted alginate lyases. Cold-adapted alginate lyases can offer advantages over the currently used alginate lyases in the industrial processes where heating is economically counterproductive or where low temperatures are required. In addition, there can also be considerable energy savings for those reactions that can be efficiently conducted at lower temperatures. Cold-adapted enzymes usually have low thermal stability and can be easily inactivated at moderate temperatures, which have advantages in the industrial processes that do not permit high temperatures for enzyme inactivation.

\section{Acknowledgments}

The work was supported by National Natural Science Founda-tion of China (41176130, 41106161, 31025001, 31070061, 31000034), Hi-Tech Research and Development program of China (2011AA09070303, 2012AA092105, 2012AA092103), Natural Science Foundation of Shandong Province, PR China (JQ200910, ZR2009DZ002), and Independent Innovation Foundation of Shandong University (2009TS079).

\section{References}

1. Gacesa, P. Alginates. Carbohydr. Polym. 1988, 8, 161-182.

2. Pawar, S.N.; Edgar, K.J. Alginate derivatization: A review of chemistry, properties and applications. Biomaterials 2012, 33, 3279-3305.

3. Lee, K.Y.; Mooney, D.J. Alginate: Properties and biomedical applications. Prog. Polym. Sci. 2012, 37, 106-126.

4. Preiss, J.; Ashwell, G. Alginic acid metabolism in bacteria. I. Enzymatic formation of unsaturated oligosac-charides and 4-deoxy-L-erythro-5-hexoseulose uronic acid. J. Biol. Chem. 1962, 237, 309-316.

5. Kim, D.E.; Lee, E.Y.; Kim, H.S. Cloning and characterization of alginate lyase from a marine bacterium Streptomyces sp. ALG-5. Mar. Biotechnol. 2009, 11, 10-16.

6. Gacesa, P. Enzymic degradation of alginates. Int. J. Biochem. 1992, 24, 545-552.

7. Osawa, T.; Matsubara, Y.; Muramatsu, T.; Kimura, M.; Kakuta, Y. Crystal structure of the alginate (poly alpha-L-guluronate) lyase from Corynebacterium sp. at 1.2 A resolution. J. Mol. Biol. 2005, 345, 1111-1118.

8. Caborhydrate-Active enZYmes (CAZy) database. Available online: http://www.cazy.org/fam/ acc_PL.html (accessed on 24 September 2012).

9. Wong, T.Y.; Preston, L.A.; Schiller, N.L. ALGINATE LYASE: Review of major sources and enzyme characteristics, structure-function analysis, biological roles, and applications. Annu. Rev. Microbiol. 2000, 54, 289-340.

10. Sawabe, T.; Tanaka, R.; Iqbal, M.M.; Tajima, K.; Ezura, Y.; Ivanova, E.P.; Christen, R. Assignment of Alteromonas elyakovii KMM $162 \mathrm{~T}$ and five strains isolated from spot-wounded fronds of Laminaria japonica to Pseudoalteromonas elyakovii comb. nov. and the extended description of the species. Int. J. Syst. Evol. Microbiol. 2000, 50, 265-271. 
11. Li, J.W.; Dong, S.; Song, J.; Li, C.-B.; Chen, X.-L.; Xie, B.-B.; Zhang, Y.-Z. Purification and characterization of a bifunctional alginate lyase from Pseudoalteromonas sp. SM0524. Mar. Drugs 2011, 9, 109-123.

12. Lee, Y.K.; Jung, H.J.; Lee, H.K. Marine bacteria associated with the Korean brown alga, Undaria pinnatifida. J. Microbiol. 2006, 44, 694-698.

13. Engel, A.S.; Porter, M.L.; Stern, L.A.; Quinlan, S.; Bennett, P.C. Bacterial diversity and ecosystem function of filamentous microbial mats from aphotic (cave) sulfidic springs dominated by chemolithoautotrophic "Epsilonproteobacteria". FEMS Microbiol. Ecol. 2004, 51, 31-53.

14. Kumar, S.; Tamura, K.; Nei, M. MEGA3: Integrated software for Molecular Evolutionary Genetics Analysis and sequence alignment. Brief. Bioinform. 2004, 5, 150-163.

15. Green, F., III; Clausen, C.A.; Highley, T.L. Adaptation of the Nelson-Somogyi reducing-sugar assay to a microassay using microtiter plates. Anal. Biochem. 1989, 182, 197-199.

16. Boyd, J.; Turvey, J.R. Structural studies of alginicacid, using abacterial poly- $\alpha$-L-guluronate lyase. Carbohydr. Res. 1978, 66, 8.

17. Ostgaard, K. Determination of alginate composition by a simple enzymatic assay. Hydrobiologia 1993, 260-261, 513-520.

18. Declan, M.; Butler, K.Ø.; Catherine, L.V.; Evans, A.J.; Kloareg, B. Isolation conditions for high yields of protoplasts from Laminaria saccharina and L. digitata (Phaeophyceae). J. Exp. Bot. 1989, 40, 1237-1246.

19. Quatrano, R.S.; Stevens, P.T. Cell wall assembly in Fucus zygotes: I. Characterization of the polysaccharide components. Plant Physiol. 1976, 58, 224-231.

20. Heyraud, A.; Colin-Morel, P.; Gey, C.; Chavagnat, F.; Guinand, M.; Wallach, J. An enzymatic method for preparation of homopolymannuronate blocks and strictly alternating sequences of mannuronic and guluronic units. Carbohydr. Res. 1998, 308, 417-422.

21. Iwamoto, M.; Kurachi, M.; Nakashima, T.; Kim, K.; Yamaguchi, K.; Oda, T.; Iwamoto, Y.; Muramatsu, T. Structure-activity relationship of alginate oligosaccharides in the induction of cytokine production from RAW264.7 cells. FEBS Lett. 2005, 579, 4423-4429.

22. Akiyama, H.; Endo, T.; Nakakita, R.; Murata, K.; Yonemoto, Y.; Okayama, K. Effect of depolymerized alginates on the growth of bifidobacteria. Biosci. Biotechnol. Biochem. 1992, 56, 355-356.

23. Mrsny, R.J.; Lazazzera, B.A.; Baughety, A.L.; Schiller, N.L.; Patapoff, T.W. Addition of a bacterial alginate lyase to purulent $\mathrm{CF}$ sputum in vitro can result in the disruption of alginate and modification of sputum viscoelasticity. Pulm. Pharmacol. 1994, 7, 357-366.

24. Wargacki, A.J.; Leonard, E.; Win, M.N.; Regitsky, D.D.; Santos, C.N.S.; Kim, P.B.; Cooper, S.R.; Raisner, R.M.; Herman, A.; Sivitz, A.B.; et al. An engineered microbial platform for direct biofuel production from brown macroalgae. Science 2012, 335, 308-313.

(C) 2012 by the authors; licensee MDPI, Basel, Switzerland. This article is an open access article distributed under the terms and conditions of the Creative Commons Attribution license (http://creativecommons.org/licenses/by/3.0/). 